Original Scientific Article

\title{
FREQUENCY OF CONTAMINATION WITH LISTERIA MONOCYTOGENES OF RAW DRIED CURED VACUUM PACKED SAUSAGES
}

\author{
Hristo Daskalov ${ }^{1}$, Fejzulla Fejzullah ${ }^{2}$, Alexandra Daskalova ${ }^{3}$ \\ ${ }^{1}$ National Diagnostic and Research Veterinary Institute, \\ BFSA, 1606 Sofia, Bulgaria \\ ${ }^{2}$ State University of Tetovo, 1200 Tetovo, Macedonia \\ ${ }^{3}$ Faculty of Veterinary Medicine, Trakia University, \\ 6000 Stara Zagora, Bulgaria
}

Received 5 September 2013; Received in revised form 8 October 2013; Accepted 20 October 2013

\begin{abstract}
The aim of this study was to collect actual data concerning the frequency of contamination with Listeria monocytogenes of some raw dried cured vacuum packed sausages, which are very popular in Bulgaria produced from Oct. 2004 till May 2008. 148 vacuum-packed samples were taken from 9 different food business operators during all seasons of the year. The samples were analyzed according to the USDA method for meat foods. Ten specimens were positive for presence of Listeria monocytogenes, which is equal to $6,75 \%$ of all tested samples. In two other raw dried cured sausages L.welshimeri and L.innocua were found, but these species are not pathogenic for consumers. In the period before the official implementation of the HACCPsystem (01.01.2006) in Bulgaria, 52 samples were examined and 5 Listeria monocytogenes isolates were found $(\sim 10 \%)$. 2,5 years after the HACCP implementation, 96 specimens from the same meat factories were tested and 5 Listeria monocytogenes isolates $(5,2 \%)$ were detected. Samples taken from lots, produced in winter time were contaminated with Listeria monocytogenes more often (7 of all 10) than specimens taken during other seasons. Data was discussed through the point of view of the effectiveness of hygienic practices and HACCP system application. Also, application of the 'microbiological criterion' set in the COMMISSION REGULATION (EC) No 2073/2005 for ready-to-eat foods unable to support the growth of L. monocytogenes was considered.
\end{abstract}

Key words: L.monocytogenes; raw dried sausage; contamination; HACCP

\section{INTRODUCTION}

Raw cured shelf-stable meat sausages are very popular in Bulgaria. This group of products includes some low-acid dried sausages and high-acid fermented sausages with high microbial stability (9). The significance of Listeria monocytogenes as a foodborne pathogen is complex. The severity and case-fatality rate of the disease require appropriate preventive measures, but the characteristics of the bacteria make it unrealistic to expect that all food

Corresponding author: Prof. Hristo Daskalov, $\mathrm{PhD}$

E-mail address: hdaskal@hotmail.com

Present address: National Diagnostic and Research Veterinary Institute

Bulgarian Agency of Food Safety

15 Blvd. Pencho Slaveykov, 1606 Sofia, BULGARIA

tel: +35929523903/mob: +359888764710

Copyright: (C) 2014 Daskalov H. This is an open-access article published under the terms of the Creative Commons Attribution License which permits unrestricted use, distribution, and reproduction in any medium, provided the original author and source are credited.

Competing Interests: The authors have declared that no competing

interests exist.

Available Online First: 15 November 2013

http://dx.doi.org/10.14432/j.macvetrev.2013.10.003 could be Listeria-free (16). According to Data (4), L.monocytogenes was isolated from various acidic foods, including sausages. The author noted that L.monocytogenes could be inactivated more easily by the stomach and intestinal $\mathrm{pH}$ and hence it would have higher infective dose, compared to some other food-borne pathogens. Recently it was noted that L.monocytogenes could possibly grow in sausage mix if there was fermentation failure (8). Also it was emphasized that during normal fermentation, drying and ripening there was a 10 to 100 -fold decrease in L.monocytogenes counts. A low number of microorganisms could be found in the finished product which would not be able to multiply $(11,12)$. A possible benefit of the microbiological risk assessment (MRA) document for Listeria monocytogenes, developed jointly by the USFDA and the USDA for risk ranking of ready-to-eat foods in 20 food categories (one of them is raw cured dried meat products) was noted (7). There is opinion mentioned that the primary sources responsible for 
introduction of L. monocytogenes into the processing environment had not been clearly identified (10). In the case of processing of raw cured dried meat products, contamination of sausage ingredients played the main role.

Raw cured dried meat products can be included into the group of ready-to-eat (RTE) foods unable to support the growth of L. monocytogenes, set in Chapter 1. "Food safety criteria" of the Commission Regulation (EC) No 2073/2005 in case of examination of $\mathrm{pH}$ and water activity $\left(\mathrm{a}_{\mathrm{w}}\right)$ of the tested batch. EFSA opinion (6) concluded that the actual data did not provide a clear picture of the risk of listeriosis. Based on the dose-response relationship of L. monocytogenes, the risk of listeriosis is mostly related to products with high concentrations of the pathogen. Thus it is important to analyze the actual concentration of the pathogen in RTE products and especially the percentage of products with high concentrations.

The aim of this study was to collect actual data concerning the frequency of contamination with Listeria monocytogenes of some raw dried cured vacuum packed sausages very popular in Bulgaria, produced from Oct. 2004 till May 2008 in different meat producing plants.

\section{MATERIALS AND METHODS}

\section{Sampling}

148 different kinds of raw cured dried meat sausages were studied. All of them were vacuum- packed in meat factories and prepared for sale without any other treatments. All samples were taken from 9 different food business operators during all seasons included in the period of study (Oct. 2004 - May 2008). All tested specimens were kept at storage temperature from 0 to $4^{\circ} \mathrm{C}$. The samples were transported and received at the laboratory up to 72 hours after processing.

\section{Microbiological analysis}

The samples were analyzed according to the USDA method for meat foods, described by Ryser and Donelly (15). Five colonies testing positive on PALCAM agar (Merck, Darmstadt) were taken and reinoculated on TSAYE agar (Merck, Darmstadt). Further examination comprised Gram staining, motility at $20-25^{\circ} \mathrm{C}$, growth at $35^{\circ} \mathrm{C}$, catalase activity (Hydrogen peroxide, Merck, Darmstadt), oxidase reaction (Oxidase reagent, bioMerieux) and $\beta$-hemolysis on blood agar (Merck, Darmstadt). Additionally, biochemical identification with API Listeria ID strip (bioMerieux, Inc., Hazelwood, Mo.) was done to all L.monocytogenes isolates.

\section{RESULTS}

Data showing the detected Listeria spp. strains in raw cured dried meat products are presented in Table 1 .

Table 1. Frequency of detection of Listeria spp. in raw cured dried meat products

\begin{tabular}{|c|c|c|c|c|c|}
\hline Period of time & Season & $\begin{array}{l}\text { Samples } \\
\text { (n) }\end{array}$ & $\begin{array}{l}\text { Negative } \\
\text { specimens for } \\
\text { Listeria spp. }\end{array}$ & $\begin{array}{l}\text { Positive specimens } \\
\text { for Listeria spp. }\end{array}$ & Species of Listeria \\
\hline \multirow{5}{*}{$\begin{array}{c}\text { 01.10. } 2004-31.12 .2005 \\
\text { (before the official } \\
\text { implementation of } \\
\text { HACCP) }\end{array}$} & Autumn & 12 & 11 & 1 & L.monocytogenes \\
\hline & Winter & 13 & 11 & 2 & \multirow[t]{2}{*}{ L.monocytogenes } \\
\hline & Spring & 9 & 9 & 0 & \\
\hline & Summer & 10 & 9 & 1 & \multirow{2}{*}{$\begin{array}{l}\text { L.monocytogenes } \\
\text { L.monocytogenes }\end{array}$} \\
\hline & Autumn & 8 & 7 & 1 & \\
\hline \multirow{8}{*}{$01.01 .2006-31.05 .2008$} & Winter & 12 & 9 & 3 & \multirow[t]{4}{*}{ L.monocytogenes } \\
\hline & Spring & 13 & 12 & 0 & \\
\hline & Summer & 11 & 11 & 0 & \\
\hline & Autumn & 11 & 11 & 0 & \\
\hline & Winter & 12 & 10 & 2 & \multirow{4}{*}{$\begin{array}{l}\text { L.monocytogenes } \\
\text { L.innocua } \\
\text { L.welshimeri }\end{array}$} \\
\hline & Spring & 12 & 11 & 1 & \\
\hline & Summer & 12 & 11 & 1 & \\
\hline & Autumn & 13 & 13 & 0 & \\
\hline \multirow[b]{2}{*}{$01.10 .2004-31.05 .2008$} & & \multirow[b]{2}{*}{$148(100 \%)$} & \multirow[b]{2}{*}{$136(91,9 \%)$} & $12(8,1 \%)$ & \multirow{2}{*}{$\begin{array}{l}\text { L.monocytogenes } \\
\text { L.innocua } \\
\text { L.welshimeri }\end{array}$} \\
\hline & & & & $\begin{array}{l}6,75 \% \text { positive for } \\
\text { L.monocytogenes }\end{array}$ & \\
\hline
\end{tabular}


Ten specimens were positive for presence of Listeria monocytogenes, equal to $6,75 \%$ of the 148 tested samples. In two other raw dried cured sausages L.welshimeri and L.innocua were found, but these species are not pathogenic for consumers. In the period before the official implementation of HACCP system (01.01.2006) in Bulgaria, 52 samples were examined and 5 Listeria monocytogenes isolates were found $(\sim 10 \%) .2,5$ years after the HACCP implementation, 96 specimens from the same meat factories were tested and 5 Listeria monocytogenes isolates $(5,2 \%)$ were detected. Samples taken from lots, produced in winter time were contaminated with Listeria monocytogenes more often ( 7 of all 10) than specimens taken during other seasons.

Results for morphological and biochemical characteristics of isolated Listeria spp. strains and their biochemical profile are shown in Table 2.

\section{DISCUSSION}

Results of the study showed presence of L.monocytogenes and some other representatives of Listeria spp. in ready-to-eat raw cured dried sausages, produced in Bulgarian meat plants. Frequency of reporting of L.monocytogenes was $6,75 \%$ of all tested samples.

On the other hand specimens examined before the HACCP implementation showed higher frequency of contamination $(9,6 \%)$, compared to samples tested after application of this system $(5,2 \%)$. All 10 isolates had similar characteristics and biochemical profile. One of the tested samples was positive for L.innocua and another showed presence of L.welshimeri. In Brazil there was evalution of raw cured meat products for occurrence of Listeria monocytogenes. The pathogen was detected

Table 2. Morphological and biochemical characteristics of Listeria spp. isolated from raw cured dried meat products

\begin{tabular}{lccccccc}
\hline $\begin{array}{c}\text { Species of Listeria } \\
\text { (Number of isolated } \\
\text { strains) }\end{array}$ & $\begin{array}{c}\text { Gram } \\
\text { staining }\end{array}$ & $\boldsymbol{\beta}$-hemolysis & $\begin{array}{c}\text { Catalase } \\
\text { activity }\end{array}$ & $\begin{array}{c}\text { Motility at } \\
\mathbf{2 0 - 2 5 ^ { \circ } \mathbf { C }}\end{array}$ & $\begin{array}{c}\text { Growth at } \\
\mathbf{3 5}^{\circ} \mathbf{C}\end{array}$ & $\begin{array}{c}\text { Oxidase } \\
\text { reaction }\end{array}$ \\
\hline L.monocytogenes & $(10)$ & + & + & + & + & + & - \\
L.innocua & $(1)$ & + & - & + & + & + & - \\
L.welshimeri & $(1)$ & + & - & + & + & + & - \\
\hline
\end{tabular}

API Listeria biochemical profile of Listeria spp. isolated from the tested food samples

\begin{tabular}{|c|c|c|c|c|c|c|c|c|c|c|c|c|}
\hline & DIM & ESC & $\alpha M A N$ & DARL & XYL & RHA & MDG & RIB & G1P & TAG & $\beta$ ВЕМ & Profile \\
\hline L.monocytogenes & - & + & + & + & - & + & + & - & - & - & + & 6510 \\
\hline L.innocua & + & + & + & + & - & + & + & - & - & - & - & 7510 \\
\hline L.welshimeri & + & + & + & + & + & + & + & - & - & + & - & 7711 \\
\hline
\end{tabular}

*Legend: DIM - enzymatic substrate; ESC - esculin; $\alpha$ MAN - 4-nitrophenyl- $\alpha$ D-manopyranoside; DARL - D-Arabitol; XYL - D-Xylose; RHA - L-Rhamnose; MDG - methyl- $\alpha$ D-glucopiranoside; RIB - D-Ribose; G1P - Glucose-1-phosphate; TAG - D-tagatose; $\beta$ HEM - $\beta$-haemolytic activity

All L.monocytogenes isolates had similar morphological and biochemical characteristics and when tested with API Listeria, the biochemical profile was 6 510. L.innocua isolate showed lack of $\beta$-hemolytic ability, positive reaction to DIM, negative to XYL, RIB, G1P, and TAG, and biochemical profile 7510 . L.welshimeri isolate did not present $\beta$-hemolytic activity and manifested positive result to DIM, negative reaction to RIB and G1P and biochemical profile 7711 . in $13.3 \%$ of Italian type samples of salami, while L. innocua occurred in $6.5 \%$ of the Italian type and in $16.6 \%$ of the Milanese type (2). In Turkey Listeria spp. and L. monocytogenes from 63 (21\%) and $35(11.6 \%)$ of the tested Turkish style fermented sausages (sucuk) (3). In USA it was proven that the cumulative 3-y L.monocytogenes prevalence for dry and semidry fermented sausages was $3.25 \%$. This kind of sausages is very popular also in Bulgaria and 4 of 10 of our L.monocytogenes isolates were isolated from this type of raw 
cured dried product (13). Opinion was noted that processing facilities were frequently contaminated with nonpersistent or persistent L. monocytogenes, which played an important role in contamination of the products. The contamination status of processing lines and machines was influenced by the compartmentalization of the processing line, with poor compartmentalization increasing the risk of L. monocytogenes presence (14). Data was presented that L. monocytogenes had the ability to adhere to stainless steel, but significant differences existed in the ability of various L. monocytogenes strains to attach to the surface.

Dust contaminated with L. monocytogenes was another source of contamination (5). Some results remarked that food safety incidents due to the growth of pathogenic bacteria such as Listeria monocytogenes in fermented sausage might provoke serious consequences for consumers (17).

To protect consumers from L.monocytogenes in ready-to-eat foods unable to support its growth, a 'microbiological criterion' set in the COMMISSION REGULATION (EC) No 2073/2005 for maximum level of $100 \mathrm{CFU} / \mathrm{g}$ products during their shelf-life was applied.

\section{CONCLUSION}

Frequency of contamination with L.monocytogenes of the tested raw cured dried sausages for the study period was $6,75 \%$. The level of contamination was higher in the period before the implementation of the HACCP system in meat producing plants. Winter season was the time with higher prevalence of L.monocytogenes. Rarely some other Listeria spp. were found.

\section{ACKNOWLEDGEMENT}

To Faculty of Veterinary Medicine, Trakia University, Stara Zagora for sponsoring Project 12/2004 and Project $17 / 2006$ and food processors for the help to conduct the research activities.

\section{REFERENCES}

1. EU Regulation 2073/2005 of 15 November 2005 on microbiological criteria for foodstuffs. Official Journal of the European Union, 338, pp. $1-29$.
2. Borges, M. de F., de Siqueira, R.S., Bittencourt, A.M., Vanetti, M.C.D., Gomide, L.A.M. (1999). Occurrence of Listeria monocytogenes in salami. Revista de Microbiologia, 30, 362-364.

3. Colak, H., Hampikyan, H., Ulusoy, B., Bingol, E.B. (2007). Presence of Listeria monocytogenes in Turkish style fermented sausage (sucuk). Food Control, 18, 30-32.

4. Datta, A.R. (2003). Listeria monocytogenes. In Marianne D. Miliotis and Jeffrey W. Bier (Eds). International Handbook of Foodborne Pathogens. (pp. 116-132). Marcel Dekker, Inc., New York

5. De Roin, M.A, Foong, S.C, Dixon, P.M, Dickson, J.S. (2003). Survival and recovery of Listeria monocytogenes on ready-to-eat meats inoculated with a desiccated and nutritionally depleted dustlike vector. J. Food Prot., 66, 962-969.

6. EFSA Panel on Biological Hazards (BIOHAZ) (2012). Scientific Opinion on a review on the European Union Summary reports on trends and sources zoonoses, zoonotic agents and food-borne outbreaks in 2009 and 2010 - specifically for the data on Salmonella, Campylobacter, verotoxigenic Escherichia coli, Listeria monocytogenes and foodborne outbreaks. EFSA Journal, 10 (6): 2726, pp. 25, www.efsa.europa.eu/efsajournal

7. Wachsmuth, K., Kause, J., Maczka, C., Ebel, E., Schlosser, W., Anderson, S. (2003). Microbial Risk Assessment as a Tool for Guiding Food Safety. In Marianne D. Miliotis and Jeffrey W. Bier (Eds). International Handbook of Foodborne Pathogens. (pp. 785-799). Marcel Dekker, Inc., New York

8. Glass, K.A., Doyle, M.P. (1989). Fate and thermal inactivation of Listeria monocytogenes in beaker sausage and pepperoni. J. Food Protect. 52, 226-231.

9. ICMSF (International Commission on Microbiological Specifications for Foods). (2000). Microorganisms in foods 6. Microbial ecology of food commodities. Aspen Publishers, Inc. Gaithersburg, Maryland

10. Oliver, H.F., Wiedmann, M., Boor, K.J. (2007). Environmental Reservoir and Transmission into the Mammalian Host. In Howard Goldfine and Hao Shen (Eds). Listeria monocytogenes: Pathogenesis and Host Response. (pp. 111-138). Springer Science\&Business Media, LLC.

11. Johnson, J.L., Doyle, M.P., Cassens, R.G., Schoeni, J.L. (1988). Fate of Listeria monocytogenes in tissues of experimentally infected cattle and in hard salami. Appl. Environ. Microbiol., 54, 497-501.

12. Junttila, J., Hirn, J., Hill, P., Nurmi, E. (1989). Effect of different levels of nitrite and nitrate on the survival of Listeria monocytogenes during the manufacture of fermented sausage. J. Food Prot., $52,158-161$ 
13. Levine, P., Rose, B., Green, S., Ransom, G., Hill, W, (2001). Pathogen testing of ready-to-eat meat and poultry products collected at federally inspected establishments in the United States, 1990 to 1999. J. Food Prot. 64, 1188-1193.

14. Lunden, J.M.,Autio, T.J., Sjoberg,A.M., Korkeala,H.J. (2003). Persistent and nonpersistent L. monocytogenes contamination in meat and poultry processing plants. J. Food Prot., 66, 2062-2069.

15. Ryser, E.T., Donnelly, C.W. (2001). Listeria. In F.P. Downes and K. Ito (Eds.). Compendium of Methods for the Microbiological Examination of Foods. (pp. 343-357), Fourth Edition, APHA.
16. Swaminathan, B. (2001). Listeria monocytogenes. In Michael P. Doyle, Larry R. Beuchat, Thomas J. Montville (Eds), Food Microbiology: fundamentals and frontiers $-2^{\text {nd }}$ ed. (pp. 383-409). ASM Press, Washington, DC.

17. Työppönen,S.,Markkula,A.,Petaja.,E.,Suihko,M.L., Mattila-Sandholm, T. (2003). Survival of Listeria monocytogenes in North European type dry sausages fermented by bioprotective meat starter cultures. Food Control, 14 (3), 181-185. 